\title{
Segmental omental infarction: an unusual cause of acute abdomen
}

\author{
José de Arimatéia Batista Araújo Filho ${ }^{a}$, João Augusto dos Santos Martines ${ }^{b}$, \\ Brenda Margatho Ramos Martines ${ }^{b}$, Rodrigo Montenegro Lourenção ${ }^{c}$, \\ Lorena Elaine Amorim Pinto ${ }^{a}$, Cláudio Campi de Castro ${ }^{b, d}$
}

Araújo Filho JAB, Martines JAS, Martines BMR, Lourenção RM, Pinto LEA, Castro CC. Segmental omental infarction: an unusual cause of acute abdomen. Autopsy Case Rep [Internet]. 2012;2(2):43-47. http://dx.doi.org/10.4322/acr.2012.016

\section{ABSTRACT}

Omental infarction is a rare cause of acute abdominal pain, and the cause of omental infarction itself remains unknown. The diagnosis of omental infarction is occasionally made intra-operatively, because it is poorly known and presents no specific clinical features. Therefore omental infarction should always be considered in the differential diagnosis of abdominal inflammatory processes, mainly those affecting the right lower quadrant. The increasing use of computed tomography in cases of acute abdomen has facilitated the diagnosis of omental infarction in the pre-operative period. Here, we present the case of a 36-year-old, overweight female patient with clinical symptoms of acute abdomen. Computed tomography of the abdomen revealed indications of omental infarction. The patient was treated conservatively with analgesics and a nonsteroidal anti-inflammatory. The clinical evolution was favorable.

Keywords: Abdomen, Acute; Infarction; Omentum; Tomography; X-Ray computed.

\section{CASE REPORT}

A 36-year-old female patient presented to the emergency room with a 5-day history of severe abdominal pain and constipation. She reported nausea, vomiting, and fever on the first day of the symptoms. Her medical history included diabetes mellitus, for which she was taking oral hypoglycemic agents and insulin. Physical examination revealed good overall health. The patient was afebrile and hydrated, with a ruddy complexion. She had a blood pressure of $220 / 120 \mathrm{mmHg}$, a pulse rate of $110 \mathrm{bpm}$, and a body mass index of $27 \mathrm{~kg} / \mathrm{m}^{2}$. Abdominal examination showed diffuse tenderness and signs of peritoneal irritation with positive rebound (Bloomberg sign). Bowel sounds were normal.
Laboratory test results were normal except for mild leukocytosis $\left(12,000\right.$ cells $\left./ \mathrm{mm}^{3}\right)$ with no shift to the left. Amylase and urinalysis were normal, and urine culture was negative for bacterial growth. Given the clinical suspicion of acute inflammatory abdomen, the patient underwent computed tomography (CT) of the abdomen with oral contrast. The CT scan showed a circumscribed heterogeneous mass permeated with streaks of low attenuation (fat), accompanied by increased density of the adjacent fat tissue, confined to the right lower quadrant. The lesion measured $7.4 \times 3.0 \mathrm{~cm}$ on its longest axis and was located between the abdominal wall and the small bowel, not involving the wall of the colon. A

\footnotetext{
${ }^{a}$ Heart Institute - Hospital das Clínicas - Faculdade de Medicina - Universidade de São Paulo, São Paulo/SP - Brazil.

${ }^{\text {b } D i a g n o s t i c ~ I m a g i n g ~ S e r v i c e ~-~ H o s p i t a l ~ U n i v e r s i t a ́ r i o ~-~ U n i v e r s i d a d e ~ d e ~ S a ̃ o ~ P a u l o, ~ S a ̃ o ~ P a u l o / S P ~-~ B r a z i l . ~}$

${ }^{c}$ Department of Clinical Surgery - Faculdade de Medicina - Universidade de São Paulo, São Paulo/SP - Brazil.

${ }^{\mathrm{d}}$ Department of Radiology - Faculdade de Medicina - Universidade de São Paulo, São Paulo/SP - Brazil.
}

Copyright $\odot 2012$ Autopsy and Case Reports - This is an Open Access article distributed of terms of the Creative Commons Attribution NonCommercial License (http://creativecommons.org/licenses/by/3.0/) which permits unrestricted non-commercial use, distribution, and reproduction in any médium provided article is properly cited. 
thin layer of free fluid was detected in the abdominal cavity; the appendix and other abdominal organs were normal in appearance (Figures 1 and 2). All of these findings are suggestive of segmental infarction of the omentum. Therefore, a conservative therapeutic regimen was addopted, consisting of analgesics, a nonsteroidal anti-inflammatory, and clinical follow up.

The patient experienced recurrence of the pain and returned to the emergency room some days later. A new CT scan showed no significant changes, and the conservative treatment was maintained. Further follow-up evaluations were unremarkable.

\section{DISCUSSION}

Acute abdomen refers to a variety of disorders that are characterized by sudden abdominal pain of variable intensity. There is a broad spectrum of diagnostic possibilities, ranging from benign to life-threatening conditions. The duration of symptoms can be from hours to days but never exceeds seven days. Acute abdomen typically requires medical intervention, surgical or otherwise. ${ }^{1}$ According to the nature of the dominant process; acute conditions of the abdomen are produced by inflammatory, obstructive, or vascular mechanisms. $^{2}$

In the topography of the right lower quadrant, the differential diagnosis of acute abdomen encompasses a variety of inflammatory diseases, including appendicitis, diverticulitis, cholecystitis, acute terminal ileitis, appendagitis, mesenteric panniculitis, omental infarction, ${ }^{3}$ and adnexal disease. Given the non-specificity and overlap of clinical findings in these conditions, imaging methods are of great importance in the diagnostic work-up. Mindelzun et al. ${ }^{4}$ reported that approximately two thirds of all patients with acute abdominal pain have an abnormality identifiable by imaging studies. The positive results obtained with multidetector CT (MDCT) in the diagnosis of acute abdomen justify its widespread use and the fact that, despite its high cost and intrinsic morbidity, MDCT is typically chosen over other methods, such

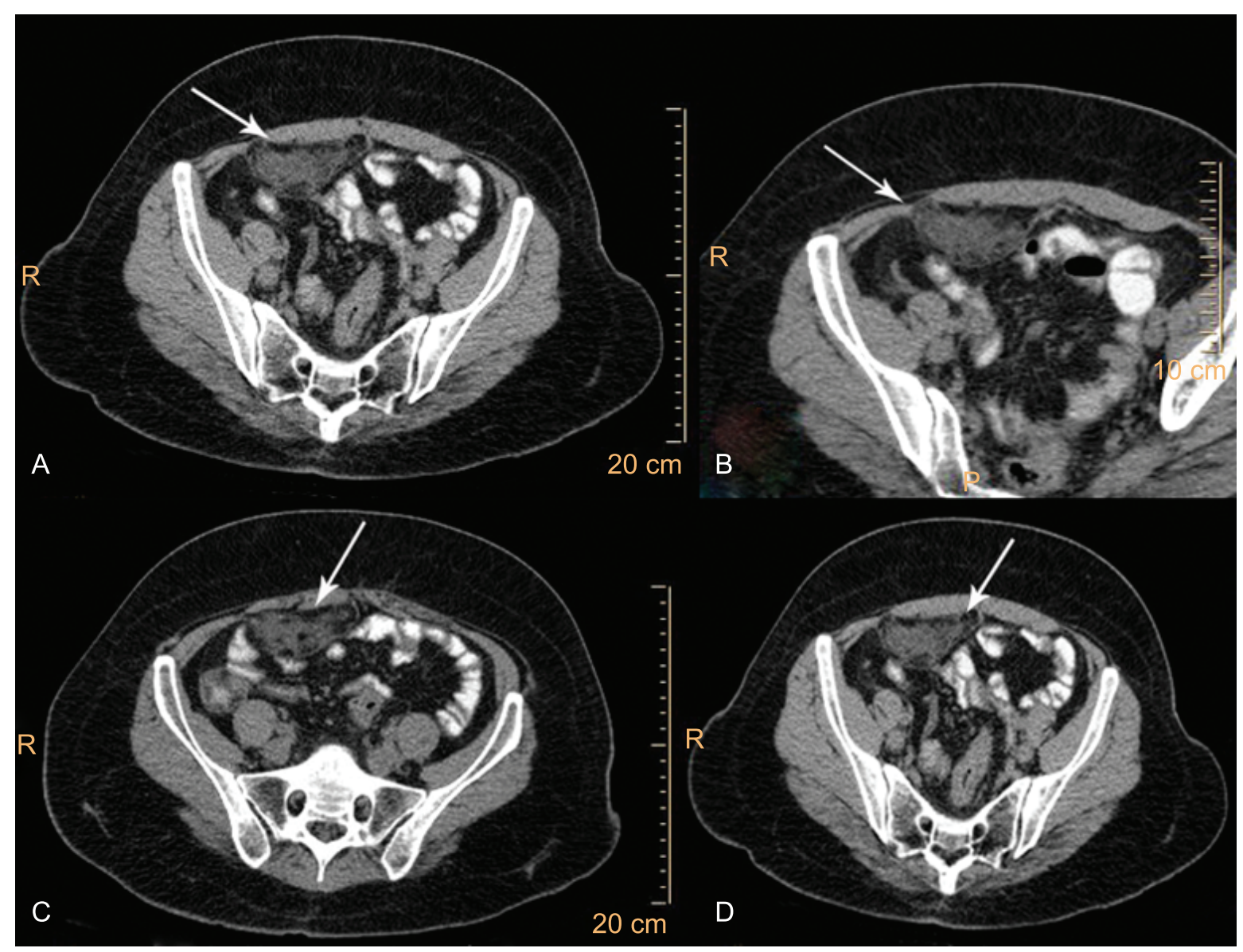

Figure 1 - Axial computed tomography of the abdomen with oral contrast media, showing a heterogeneous mass permeated by streaks of low attenuation in the right lower quadrant (white arrows), between the abdominal wall and the small bowel, to the wall of the colon. Note the preserved caliber of the appendix. 


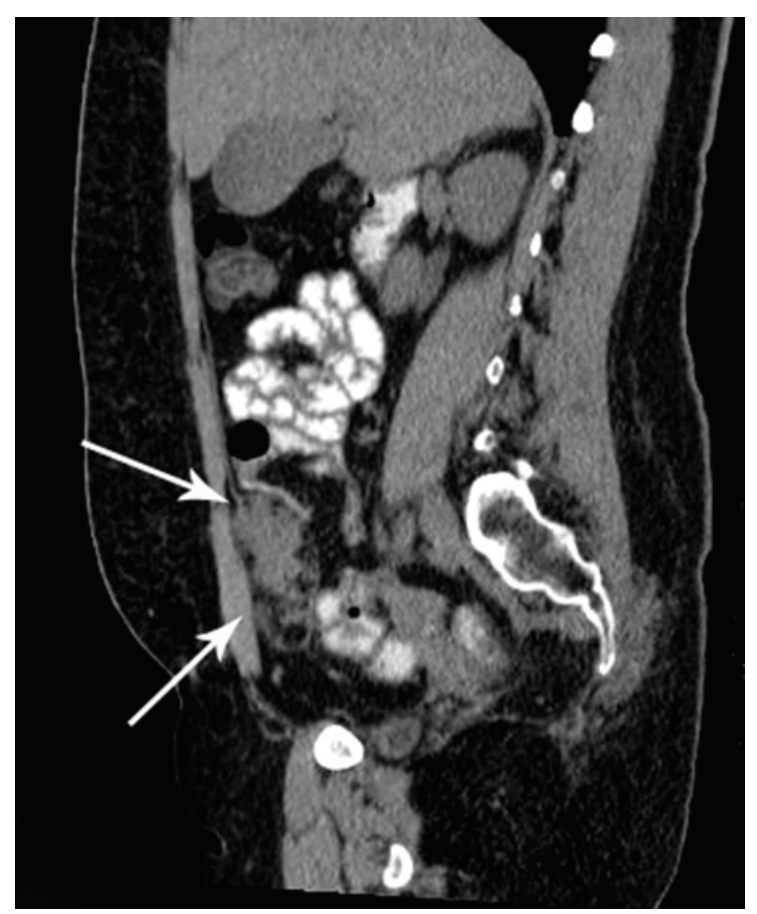

Figure 2 - MDCT of the abdomen, sagittal reformatted image showing displacement of the small bowel by the mass.

as plain radiographs and ultrasonography, for use in cases of acute abdomen. ${ }^{5}$ More recently, the use of CT without contrast has been proposed as an alternative to plain abdominal radiography for initial evaluation of patients with suspected acute abdomen. The availability CT has been increasing, as has its sensitivity and specificity. ${ }^{6}$

Considering the inflammatory processes of the abdominal right lower quadrant, acute appendicitis is considered the first hypothesis. Otherwise, clinical practice shows that, when the surgery is undertaken without a diagnostic imagining study, a diagnosis other than the one previously considered can be discovered. Omental infarction, with or without torsion, is one such incidental diagnosis. Omental infarction is a rare abdominal emergency that affects middle-aged patients, predominantly males (male/female ratio, 3:2), ${ }^{7}$ usually without an identifiable cause (idiopathic or primary infarction). The incidence of omental torsion is $0.0016 \%$, compared with $0.37 \%$ for appendicitis, or less than 4 cases per 1,000 cases of appendicitis. ${ }^{8}$ Omental infarction can occur with or without torsion. Eitel et al. first described the former in $1899,{ }^{9}$ who reported a case in which the omentum twisted along its long axis, cutting off its blood supply. However, Bush et al. ${ }^{10}$ had described infarction of the omentum without torsion in 1898, reporting a case of hemorrhage into the greater omentum. Anatomical malformations, such as a bifid or accessory omentum, cause spontaneous torsion, sudden movements, violent exercise, and hyper peristalsis having been implicated as precipitating factors. Obesity and the presence of a redundant or overly mobile omentum are also considered predisposing factors. In the study conducted by Van Breda Vriesman et al. ${ }^{11}$ in 1999 , nearly $70 \%$ of the patients with omental infarction were obese. Secondary torsions more often occur because of previous surgery, tumors, adhesions, and incarcerated hernias, with the dependent omentum becoming fixed in the contorted position and unable to untwist. ${ }^{7,8}$ Omental infarction without torsion occurs in the setting of systemic diseases such as vasculitis, as well as in hypercoagulable states and pancreatitis. Idiopathic segmental infarction can also occur. The distinction between omental torsion and omental infarction without torsion is thought to be only of academic importance. ${ }^{8}$ The literature also states that ischemic processes involve mainly the right side of the omentum, probably due to its greater size, weight, and mobility. ${ }^{7}$

Reports dating from before the advent of modern imaging modalities show the frequency of non-operative and pre-operative diagnosis of omental infarction to have been $0.6-4.8 \% .^{11,12}$ Even without intravenous contrast media, a CT scan usually furnishes the diagnosis. Findings include dense planes with the formation of a fat mass, consisting of fat necrosis, hemorrhage, and inflammatory infiltrate. The presence of linear streaking accompanied by a fat mass suggests that the omental vessels have twisted upon themselves, confirming the diagnosis of omental infarction. These findings have also been described as a whirl pattern of fat and vessels, plus caking and stranding of omental fat. ${ }^{11,13}$ In cases of secondary torsion, the CT scan can reveal concomitant or triggering processes. $^{14}$

Among the treatment modalities for omental infarction, the conservative, or expected, management with analgesics, nonsteroidal anti-inflammatory drugs, and (occasionally) antibiotics seems to be the most attractive. However, complications of such conservative management include abscess and adhesions. More importantly, a missed diagnosis of acute appendicitis could have disastrous consequences. Van Breda Vriesman et al. ${ }^{11}$ reported a series of 40 cases of intra-abdominal fat infarction treated clinically without complications. In contrast, Nubi et al. ${ }^{15}$ reported a series of 10 children diagnosed with omental infarction. Although all 
of the children were initially treated clinically, 6 subsequently required surgical intervention. In cases of persistence of the clinical manifestations, omentectomy is indicated. Omentectomy promotes immediate symptom improvement and appears to decrease the rate of complications such as abscess, intestinal obstruction, and adherences. There have been numerous reports showing that early surgical intervention, especially a laparoscopic procedure, is an appropriate treatment for omental infarction. ${ }^{16-18}$ Therefore, it is difficult to determine which is the best therapeutic option in cases of omental infarction. However, there is a trend toward greater use of conservative management as the first-line treatment.

Given the current technological advances in radiology, especially in $\mathrm{CT}$, the importance of imaging for the diagnosis of acute abdomen is undisputable. Because of the lack of specificity of clinical and laboratory data in cases of omental infarction, CT allows the timely and accurate diagnosis, as well as making surgical procedures unnecessary. Therefore, some authors now recommend the introduction of MDCT in the initial workup of acute abdomen. However, questions concerning professional training, availability, and operating costs of the method persist.

\section{REFERENCES}

1. Meneghelli UG. Elementos para o diagnóstico do abdômen agudo. Medicina (Ribeirão Preto). 2003;36(1):283-93. Portuguese.

2. Lopes AC, Reibscheid S, Szejnfeld J. Abdome agudo: clínica e imagem. São Paulo: Atheneu; 2004. Portuguese.

3. Houben $\mathrm{CH}$, Powis M, Wright VM. Segmental infarction of the omentum: a difficult diagnosis. Eur J Pediatr Surg. 2003;13(1):57-9. PMid:12664418. http://dx.doi. org/10.1055/s-2003-38289

4. Mindelzun RE, Jeffrey RB. Unenhanced helical CT for evaluating acute abdominal pain: a little more cost, a lot more information. Radiology. 1997;205(1):43. PMid:9314959.

5. Freire Filho EO, Jesus PEM, D'lppolito G, Szejnfeld J. Tomografia computadorizada sem contraste intravenoso no abdome agudo: quando e por que usar. Radiol Bras. 2006;39(1):51-62. Portuguese. http://dx.doi.org/10.1590/ S0100-39842006000100011

6. Jeffrey RB. Imaging the acute abdome: the impact of computed tomography and sonography. In: Gore MR, Levine MS, editors. Textbook of gastrointestinal radiology. 2nd ed. Philadelphia: WB Saunders; 2000. p. 2186-95.
7. Viana PCC, Pinho MC, Ormond Filho A, Chate RC, Menezes MR. Qual o seu diagnóstico? Radiol Bras. 2004;37(3):v-vi. Portuguese.

8. Itenberg E, Mariadason J, Khersonsky J, Wallack M. Modern management of omental torsion and omental infarction: a surgeon's perspective. J Surg Educ. 2010;67(1):44-7. PMid:20421090. http://dx.doi.org/10.1016/j.jsurg.2010.01.003

9. Eitel GG. Rare omental torsion. New York Med Rec.1899;55:715-6.

10. Bush P. A case of haemorrhage into the greater omentum. Lancet. 1896;1:286. http://dx.doi.org/10.1016/S01406736(01)91996-8

11. Van Breda Vriesman AC, Lohle PN, Coerkamp EG, Puylaert JB. Infarction of omentum and epiploic appendage: diagnosis, epidemiology and natural history. Eur Radiol. 1999;9(9):188692. PMid:10602970. http://dx.doi.org/10.1007/s003300050942

12. Varjavandi V, Lessin M, Kooros K, Fusunian R, McCauley R, Gilchrist B. Omental infarction: risk factors in children. J Pediatr Surg. 2003;38(2):233-5. PMid:12596111. http:// dx.doi.org/10.1053/jpsu.2003.50051

13. Pilleul F, Bonifacio A, Atri M. CT appearance of primary omental torsion: description of a new finding. J Radiol [Internet]. 2003 [cited 2012 May 7]. Available from: http:// www.jradiology.com/arts/57.pdf

14. Schwartzman GJ, Jacobs JE, Birnbaum BA. Omental infarction as a delayed complication of abdominal surgery. Clin Imaging. 2001;25(5):341-3. http://dx.doi.org/10.1016/ S0899-7071(01)00314-X

15. Nubi A, McBride W, Stringel G. Primary omental infarct; conservative versus operative management in the era of ultrasound, computerized tomography and laparoscopy. J Pediatr Surg. 2009;44(4):953-6. PMid:19433177. http:// dx.doi.org/10.1016/j.jpedsurg.2009.01.032

16. Sánchez J, Rosado R, Ramírez D, Medina P, Mezquita S, Gallardo A. Torsion of the greater omentum: treatment by laparoscopy. Surg Laparosc Endosc Percutan Tech. 2002;12(6):443-5. http://dx.doi.org/10.1097/00129689200212000-00012

17. Costi R, Cecchini S, Randone B, Violi V, Roncoroni L, Sarli L. Laparoscopic diagnosis and treatment of primary torsion of the greater omentum. Surg Laparosc Endosc Percutan Tech. 2008;18(1):102-5. http://dx.doi.org/10.1097/ SLE.0b013e3181576902

18. Ha JP, Tang CN, Siu WT, Tsui KK, Li MK. Laparoscopic management of acute torsion of the omentum in adults. JSLS. 2006;10(5):351-4. PMid:17212894 PMCid:3015694. 


\section{Conflict of interest: None}

Submitted on: $16^{\text {th }}$ March 2012

Accept on: $3^{\text {rd }}$ May 2012

Correspondence: Serviço de Iconologia

Av. Prof. Lineu Prestes, 2565 - Cidade Universitária - São Paulo/SP - Brazil

CEP 05508-900 - Phone: +55 (11) 3091-9301.

E-mail: ariaraujocg@hotmail.com 
